\title{
Fractal analysis of chromatin as a potential indicator of human exposures to ionizing radiation
}

Análise fractal da cromatina como potencial indicador de exposições humanas à radiação ionizante

\author{
A. I. S. F. Xavier ${ }^{1,2}$; M. B. Cavalcanti ${ }^{1}$; E. B. Silva ${ }^{1,3}$; A. Amaral ${ }^{1}$; T. S. \\ Fernandes ${ }^{1,2 *}$ \\ ${ }^{1}$ Laboratório de Modelagem e Biodosimetria Aplicada (LAMBDA), Universidade Federal de Pernambuco, \\ CEP:50740-540, Recife-PE, Brasil \\ ${ }^{2}$ Departamento de Biofísica e Radiobiologia, Universidade Federal de Pernambuco, CEP:50670-901, Recife-PE, \\ Brasil \\ ${ }^{3}$ Centro Acadêmico de Vitoria, Universidade Federal de Pernambuco, CEP:55608-680, Vitória de Santo Antão-PE, \\ Brasil
}

*thiagosalazar@hotmail.com

(Recebido em 04 de agosto de 2017; aceito em 18 de janeiro de 2018)

\begin{abstract}
The theory of fractals, proposed by the mathematician Mandelbrot (1975), has been applied to many fields in Biology, mainly due to the property of self-similarity observed in the natural world, such as in the DNA molecule and chromatin structure. Many researches have proven the applicability of this mathematical analysis for the identification of cells containing mutations, in the case of cancers, or due to exposures to chemicals and ultraviolet radiation, but until the present moment, no work was done with ionizing radiation. The aim of the present study was to investigate the use of fractal analysis for the identification of irradiated cells, and to discuss its potential use as an indicator of human exposures to ionizing radiation. For this, 200 cells were digitalized, where 100 were from a blood sample irradiated with an absorbed dose of 3 Gy of gamma radiation, and 100cells were non-irradiated. Fractal dimensions (FD) were calculated by the method of Box-Counting. It was possible to notice an increase in FDs of chromatin after exposure to ionizing radiation, and an overdispersion of the values of FD only in irradiated sample. Also, when the data was reorganized in crescent order, it was possible to clearly distinct the irradiated sample from the non-irradiated one. With this, we present an efficient method for the identification of irradiated human blood samples, in a fast and most simplified way, what can be of valuable importance in cases where there is a need of quick responses to human exposures to ionizing radiation.

Keywords: radiobiology, complexity, chromatin organization, box-counting, biodosimetry.
\end{abstract}

A teoria dos fractais, proposta pelo matemático Mandelbrot (1975), tem sido aplicada em muitos campos da Biologia, principalmente devido à propriedade da auto-similaridade observada no mundo natural, como na molécula de DNA e na estrutura da cromatina. Muitas pesquisas provaram a aplicabilidade desta análise matemática para a identificação de células contendo mutações, no caso de câncer, ou devido a exposições a produtos químicos e à radiação ultravioleta, mas até o presente, não há trabalhos com radiação ionizante. O objetivo do presente estudo foi investigar o uso da análise fractal para a identificação de células do sangue periférico humano irradiado e discutir o seu potencial uso como indicador de exposições humanas à radiação ionizante. Para isso, 200 células foram digitalizadas, onde 100 foram provenientes de uma amostra de sangue irradiada com uma dose absorvida de 3 Gy de radiação gama, e 100 células não foram irradiadas. As dimensões fractais (DF) foram calculadas pelo método de Box-Counting. Foi possível notar um aumento das DFs da cromatina após exposição a radiações ionizantes e uma sobredispersão dos valores de DF somente na amostra irradiada. Além disso, quando os dados foram reorganizados em ordem crescente, foi possível distinguir claramente a amostra irradiada da não irradiada. Com isso, apresentamos um método eficiente para a identificação de amostras irradiadas, de forma rápida e simplificada, o que pode ser de grande importância nos casos em que exista uma necessidade de respostas rápidas às exposições humanas à radiação ionizante.

Palavras-chave: radiobiologia, complexidade, organização da cromatina, box-Counting, biodosimetria. 


\section{INTRODUÇÃO}

The theory of fractals, introduced by the mathematician Benoit Mandelbrot in 1975, has shown to be useful to understand many of the structures and processes in many fields of science, for describing geometry closer to natural objects, which present irregular forms [1]. These objects, so-called non-linear, are found in many of the physiological processes, such as heart beating, vascular system, brain signals, and the organization of genes $[2,3,4]$.

The relationship of structural organization of chromatin and its morphological disorganization in pathological processes has been studied in fundamental and clinical sciences, with the purpose of establishing new biomedical parameters [1,5]. One of the possible morphometric parameters is the measurement of changes in fractal properties of biological tissues, such as self-similarity and fractal dimension (FD) [3,4].

This geometric pattern is found, for example, in the shape and organization of the chromatin (into the nucleus of euchariotic cells). Recently this pattern of organization was denominated "fractal globule" by Lieberman-Aiden and co-authors (2009), in which its structure follows an optimal way for compaction known mathematically as 'Peanno curve'. Also the chromosomes are regionalized and are in close relationship and proximity in 3D (three dimension), making regions that apparently are far away from each other by linear DNA sequencing to be very close in space [6]. This will interfere in genetic activity (DNA transcription) and in the condensation-decondensation transition during cell cycle, without the formation of knots.

The "equilibrium globule", another model previously proposed, does not prevent the formation of knots, as commonly happen to our headphones when we take it out from the pockets. With the fractal nature of the chromatin, works have been developed for investigating possible changes in FDs as a parameter of cellular and molecular modifications, such as in cancers [7,8,9]. This has been a growing field at NIH (National Institute of Health) and has been named as the "4D Nucleome" [10].

With this, biological fractals are dynamical processes with the characteristic of selforganization, which result in the complexity of its structure. When the structure is changed by some external agent, the function is also modified. This occurs, for example, with proteins, and also with the structure of the chromatin. Therefore, the alteration of the complexity of the structure also alters its function $[11,12]$.

Once these dynamical processes are different between normal and altered cells, the FD may be a parameter of biological changes after exposure to ionizing radiation (IR). The wellknown effect of IR on chromatin is DNA double strand breaks (DSBs), and its relation in metaphase with chromosome breaks and chromosome rearrangements. The chromosome rearrangements are the results of misrepair of the chromatin breaks (i.e. misrepair of the nonhomologous mechanism) [13]. With this, the hypothesis that raises here is that whether these molecular changes would also reflect in changes in the texture of the nucleus.

In this context, the aim of this research was to investigate the feasibility of the use of fractal dimensions of the images of nuclei, from in vitro irradiated and non-irradiated lymphocytes, as a potential indicator of human exposures to ionizing radiation.

\section{MATERIAL AND METHODS}

\subsection{Ethical aspects and samples}

This research was approved by the Human Research Ethics Committees of the Center of Health Sciences at the Federal University of Pernambuco (Number 1.102.076). The subject signed the Term of Consent before collection of blood samples. $18 \mathrm{~mL}$ of peripheral blood samples were collected, being $9 \mathrm{~mL}$ irradiated and $9 \mathrm{~mL}$ non-irradiated (control).

\subsection{Irradiation of samples}

Blood sample was irradiated with a source of Colbalt-60 (Gammacell 220 Excel - dose rate of $2.8 \mathrm{kGy} \cdot \mathrm{h}^{-1}$ ), in order to receive $3 \mathrm{~Gy}$. 


\subsection{Preparation of slides and image capture}

Slides were prepared from blood samples (irradiated and non-irradiated). The slides were stained by Panoic staining (i.e. methanol, eosin, and methylene blue). The images of cells were captured using the inversed digital microscope EVOS® XL Cell Imaging System (AMG, EUA), using the immersion objective (100X magnification), with the luminosity of $75 \%$ (3.1 megapixels). It were digitalized 100 images of irradiated cells and 100 images of non-irradiated cells. The format of the images was TIFF (Tagged Image File Format) 24 bits with 2048 x 1536 pixels.

\subsection{Image processing}

The images obtained were submitted to the segmentation process, technique in which the image is separated in regions following a criteria in order to isolate the object of interest in this research, i.e. the nucleus, using for that the software "Paint" (Microsoft Windows, version 6.1) (Figure 1A).

Following that, the images were transferred to the software Image ${ }^{\mathrm{TM}}$ from NIH (National Institute of Health), available for free download (http://rsbweb.nih.gov/ij/) (imageJ_1.46r). The first step was to convert the images to gray scale (8-bits) (Figure 1B). Due to the broad spectrum of the gray scale, the intensity of each pixel is considered as a height of that point of the image, allowing the $3 \mathrm{D}$ analysis as in living cells.

Image calculator was used to make images clearer, highlighting the texture of the chromatin (Figure 1C).

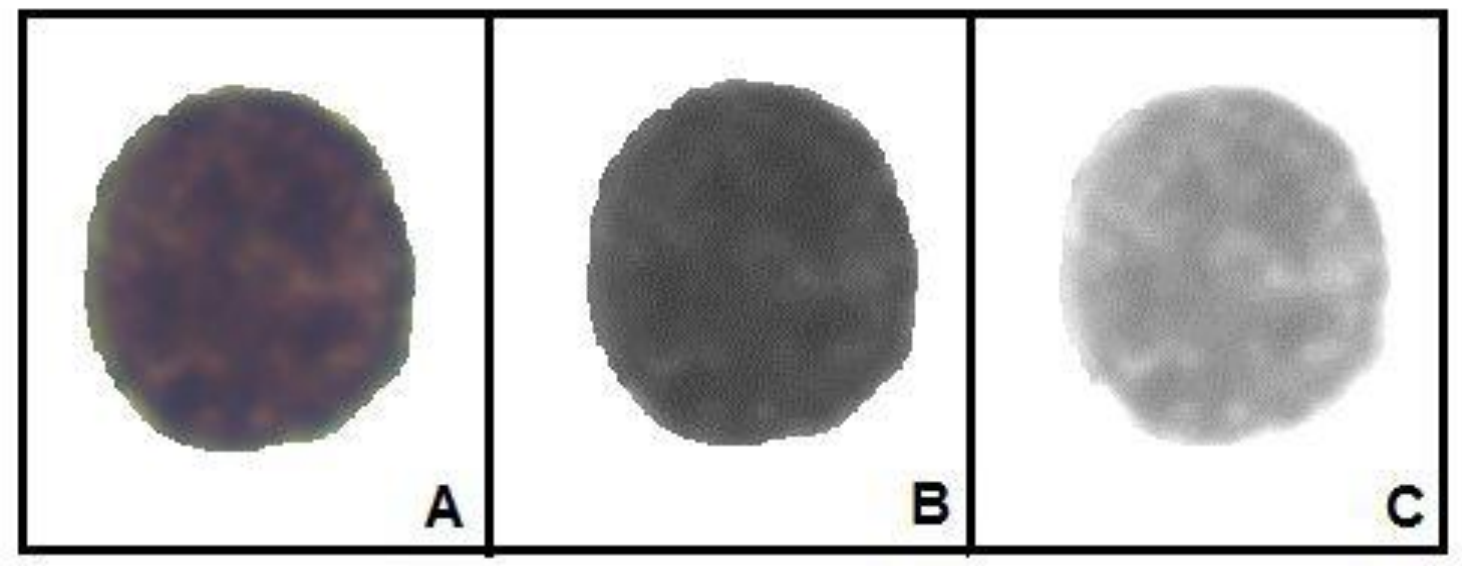

Figure 1: Image treatments of nucleus: Segmented (A), gray scale (B), and after "image calculator" $(C)$.

\subsection{Fractal analysis}

The images were submitted to fractal analysis using box-counting method of the plugin "fracLac" of the software Image ${ }^{\mathrm{TM}}$, available for free download (https://imagej.nih.gov/ij/plugins/fraclac/fraclac.html). This method consists in the superposition of boxes in the image, where the lateral of the boxes is continuously reduced in size. In each of this reduction, it is counted the number of boxes necessary to cover pixels of the image (with pixels into it).

After this, the fractal dimension (FD) is calculated by:

$$
\mathrm{FD}=\lim _{r \rightarrow 0}\left(\frac{\log N r}{\log (1 / r)}\right)
$$

Where $\mathbf{N r}$ is the number of boxes necessary to cover the image in each progressive reduction of the side of the box (r). FD will be the slope of the regression line, generated by the logarithm of the quantity of boxes in function to the logarithm of the size of the boxes. 


\subsection{Statistical analysis}

The FDs of the nucleus of irradiated lymphocytes were compared with the one of non-irradiated (control) by the t-student, in order to establish if there is some statistical difference between the groups. The statistical analysis was performed using the software Bioestat ${ }^{\mathrm{TM}}$ (version 5.3) with the limit of confidence of $95 \%$.

\section{RESULTS}

Table 1 presents the results of the mean values of FD, the maximum and minimum FD, with standard deviation and the variance of 100 irradiated cells and 100 non-irradiated ones.

Table 1: Fractal dimensions (minimum, maximum, average) of non-irradiated (control) and irradiated cells.

\begin{tabular}{ccccccc}
\hline Groups & $\begin{array}{c}\mathbf{N}^{\mathbf{0}} \\
\text { cells }\end{array}$ & $\begin{array}{c}\text { Minimum } \\
\text { FD }^{*}\end{array}$ & $\begin{array}{c}\text { Maximum } \\
\text { FD* }\end{array}$ & Mean & $\begin{array}{c}\text { Standard- } \\
\text { Deviation }\end{array}$ & Variance \\
\hline non-irradiated & 100 & 2.4669 & 2.6202 & 2.5181 & 0.030 & 0.0009 \\
\hline Irradiated & 100 & 2.4616 & 2.6323 & 2.5311 & 0.036 & 0.0013 \\
\hline
\end{tabular}

*FD - Fractal Dimension

The difference between the FDs between groups is statistically significant ( $p=0.0044)$, allowing to discriminate the irradiated sample from the non-irradiated.

When the variance is compared (Figure 2, A and B), it is possible to notice that the irradiated sample presented a higher dispersion. The ANOVA test showed a statistical difference $(\mathrm{p}=0.0064 ; \mathrm{F}=7.6264)$ between the variances followed by Tukey $(\mathrm{p}<0.01)$.

The data was reorganized in crescent order, to compare the groups in terms of each value of fractal dimension. In the Figure 3 below, it is possible to notice that the groups are indeed distinguishable in terms of values of fractal dimensions, permitting to distinguish if the sample was irradiated.

\section{DISCUSSION}

The increase of the mean of FDs in the chromatin of irradiated cells is an evidence that DNA damage induced by radiation may already be noticed in interphase chromatin configuration. Probably, the interaction of IR with the target leads to the modification of the physical topology of the global architecture of the chromatin, which lead to an increased heterogeneity of gene networks [5].

Pantic et al. (2012) [14] have evaluated the application of FD calculation in the nucleus of cells exposed to ultraviolet radiation (UV), a non-ionizing radiation, differently of the present study, in which the samples were irradiated with gamma rays. The results presented a decrease in FDs of cells due to apoptosis. In this particular biological endpoint (apoptosis), cells become more rounded and this is why the FDs in this studied were observed to present decreased values [14].

When the biological effect investigated is the transformation of cells due to tumorigenesis, such as leukemia, it can be observed that fractal dimensions indeed increase, similar to the results obtained in the present study with ionizing radiation. It is possible that radioinduced mutations change the global physical topological complexity of the chromatin, and this can be measurable by computational tools, such as the employed here.

Other important observation is the increased variance of FDs of cells belonging to the irradiated sample, as shown in Figure 2 (B). It is well-known in radiobiology that the variance exceeds the mean when the cells are irradiated with high LET radiation (e.g. neutrons, alpha particles), and the biological damage is overdispersed. But at the present work, we obtained 
evidence that even for low LET radiation (such as gamma rays), but at high dose ( $3 \mathrm{~Gy}$ ), the variation cell-to-cell is also overdispersed $[13,15]$.
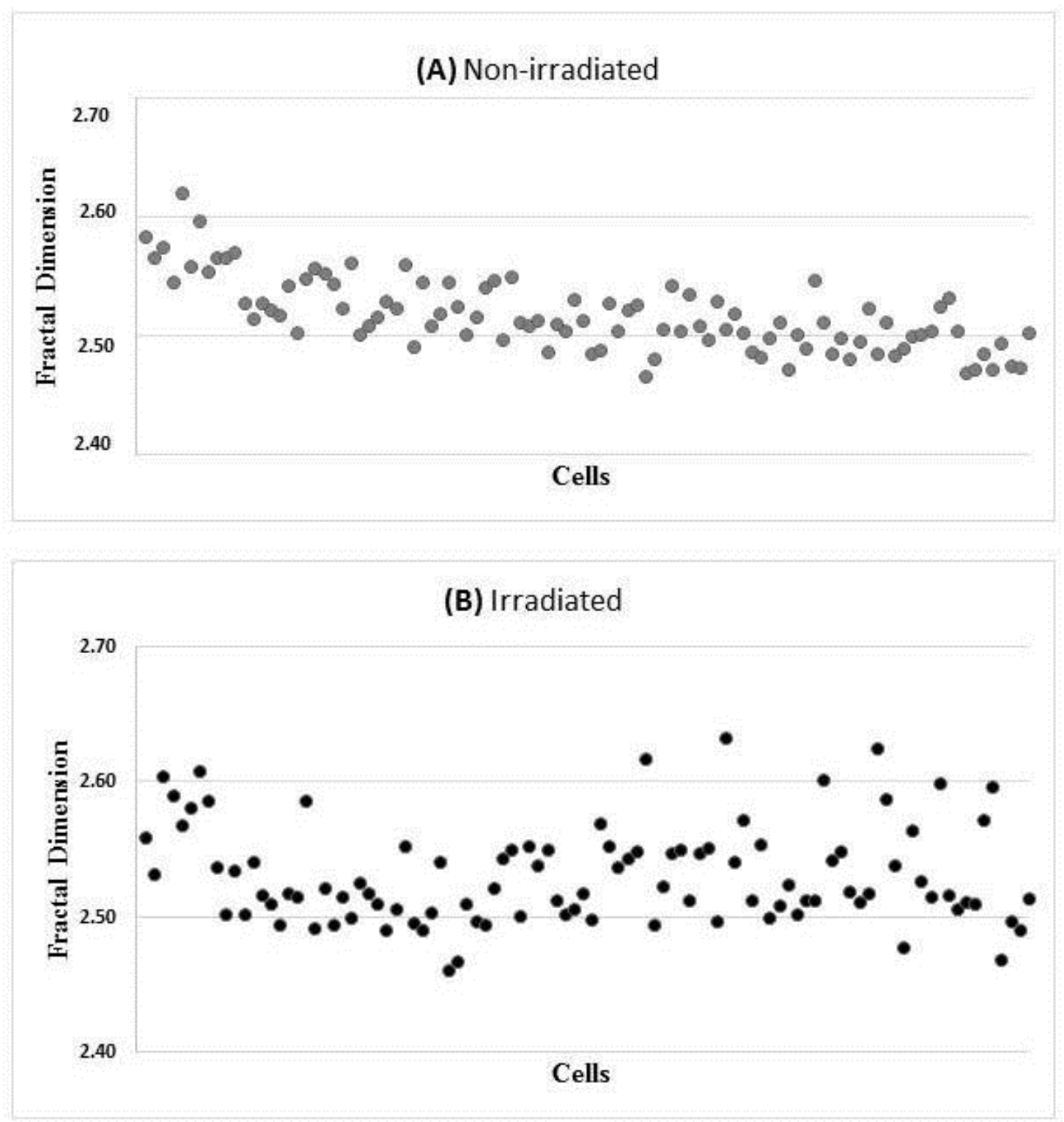

Figure 2: Variances of FD for samples non-irradiated (A) and irradiated with $3 \mathrm{~Gy}(B)$. 


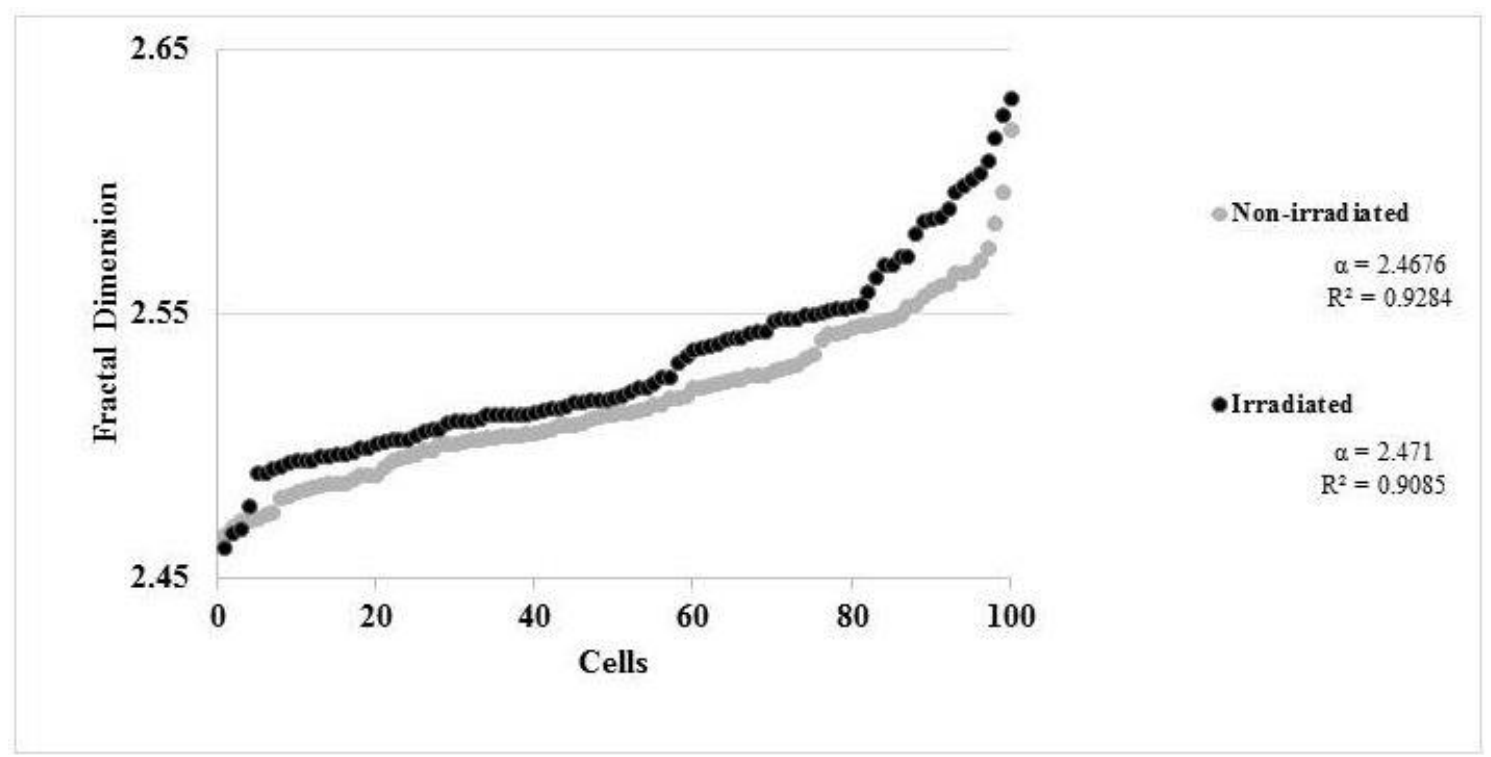

Figure 3: Crescent order distribution of fractal dimensions of cells from irradiated and non-irradiated samples.

This evidence is supported by Gruel et al. (2016) [15], who demonstrated that the variance is not constant with the increase of absorbed dose, even for low LET radiations. There are some hypotheses to explain the heterogeneity of damage among irradiated cells, such as:

1. There is a variability of time of response of irradiated cells to the signaling of damage and repair [16];

2. There is a variability of the number and energy of photons which hit the cells [17];

3. There is a difference in the state of condensation of the chromatin among cells (i.e. cells in different stages of the cell cycle), which reflect in the kinetics of damage repair. With this, regions of euchromatin are more quickly repaired (maximum of 5 minutes), and regions of heterochromatin are more slowly repaired (maximum of 30 minutes) [18].

Besides the hypothesis presented, one should considerer the volume of the target, in which the molecular changes induced by radiation will cause the global modification of chromatin architecture [5]. Recent studies have demonstrated that the volume of $1.6 \mu \mathrm{m}^{3}$ correspond exactly to the volume filled by the ligation of sugar phosphate of the nucleotides of DNA, which is precisely the region broken by the interaction with ionizing radiation directly or by free radicals, ions and free electrons produced by the radiolysis of water [15].

Such result may better explain the variability of damage among cells and the quadratic behavior of the dose-effect curve, which depend on the energy of photons/electrons hitting the cells, what have the probability of hitting the tiny region of the target and effectively producing the damage $[13,19,15]$.

Based on this discussion and on the design of the experiments of the present study, where the effects of irradiation were not studied in a time sufficient for DNA repair, the late hypothesis is well supported by our results. Even the dose being uniform, there is heterogeneity of FDs probably due to the heterogeneity of hits, energy and fluency of electrons that traverses the region of the target [15].

Also, it is possible to notice in Figure 3 that the inclination of the line of non-irradiated group is higher, but the $\mathrm{r}$ squared is smaller, when compared to irradiated group. This allows also 
inferring that the variation on fractal dimensions from non-irradiatedcells is lower, because of the reasons already discussed above: cells did not have any external stress, therefore the physical organization of chromatin are more uniform among cells.

When the methodology proposed here is compared to the conventional cytogenetics, considered the 'gold standard' for analyzing the biological damage of ionizing radiation, the present method have shown to be efficient in terms of faster analysis and response, once the cells are analyzed in G0 of cell cycle without the necessity of cell culturing, and it is less laborious, because the present method does not require the analysis of individual chromosomes. However, it should be considered that the present study did not relate the parameter of FD with absorbed doses of IR, and the dicentric is the reliable biomarker to relate dose-effect with purpose of biological dosimetry [13].

With this, this mathematical determinant would lead to a quicker response in a triage mode, if subjects have or have not been exposed to ionizing radiation. This must be of great importance when a large number of individuals have been potentially exposed to ionizing radiation.

\section{CONCLUSION}

The fractal analysis of chromatin using box-counting method showed to be a promissory morphometric method for the triage of irradiated samples (or from an irradiated subject), considering both mean and variance of FD values. Combining computational imaging acquisition with fractal geometry methods permit to better understand the physical organization of chromatin both in physiological situation and after radioinduced mutations. This protocol showed to be an easy-to-perform technique, useful for a quick answer in cases of human exposures to ionizing radiation, and for the development of software designed for the identification of chromatin alterations.

\section{ACKNOWLEDGMENT}

This work was supported by CNPq (Conselho Nacional de Desenvolvimento Científico e Tecnológico).

\section{REFERENCES}

1. Pantic I, Nesic D, Basailovic M, Cetkovic M, Mazic S, Suzic-Lazic J, et al. Chromatin fractal organization, textural patterns, and circularity of nuclear envelope in Adrenal Zona Fasciculata cells. MicroscMicroanal. 2016;22(6):1120-7, doi:10.1017/S1431927616011910

2. Mandelbrot BB. The Fractal Geometry of Nature [Internet]. Vol. 51, American Journal of Physics. 1983. 286 p., doi:10.1017/CBO9781107415324.004

3. Goutzanis L, Papadogeorgakis N, Pavlopoulos PM, Katti K, Petsinis V, Plochoras I, et al. Nuclear fractal dimension as a prognosticfactor in oral squamouscell carcinoma. Oral Oncol. 2008;44(4):34553, doi:10.1016/j.oraloncology.2007.04.005

4. Metze K. Fractal dimension of chromatin: potential molecular diagnostic applications for cancer prognosis. Expert Rev MolDiagn [Internet]. 2013;13(7):719-35, doi:10.1586/14737159.2013.828889

5. Almassalha LM, Tiwari A, Ruhoff PT, Stypula-Cyrus Y, Cherkezyan L, Matsuda H, et al. The Global Relationship between Chromatin Physical Topology, Fractal Structure, and Gene Expression. Sci Rep [Internet]. 2017 Jan;24(7)(December 2016):41061, doi:10.1038/srep41061

6. Lieberman-Aiden E, van Berkum NL, Williams L, Imakaev M, Ragoczy T, Telling A, et al. Comprehensive Mapping of Long-Range Interactions Reveals Folding Principles of the Human Genome. Science (80- ) [Internet]. 2009 Oct;9(5950):289-93. doi: 10.1126/science.1181369

7. Kerenji AS, Bozovic ZL, Tasic MM, Budimlija ZM, Klem IA, Polzovic AF. Fractal dimension of hepatocytes' nuclei in normal liver vs hepatocellular carcinoma (HCC) in human subjects Preliminary results. Arch Oncol. 2000;8(2):47-50, doi:03547310

8. Huang Z, Pan J, Chen G, Li Z, Chen X, Li Y, et al. Fractal analysis of two-photon microscopic images 
for diagnosis of nasopharyngeal cancer. Scanning. 2012;34(6):399-403, doi:10.1002/sca.21023

9. Fernades TDS, Maria I, Barros R, Álvaro L, Aguiar DA, Amaral A, et al. Non-linear dynamics induced by Colcemid of chromosome condensation. Braz Arch Biol Technol. 2013;56(February):8592, doi: $1678-4324$

10. Marx, V. Genomics in 3D and 4D. Nat. Methods. 2016;13:829-832, doi:10.1038/nmeth.4001

11. Marinelli F, Santoro R, Maraldi NM. Fractal Analysis of Heterochromatin Nuclear Domains in Lymphocytes. In: Fractals in Biology and Medicine [Internet]. Basel: Birkhäuser Basel; 1998. p. 2205, doi:10.1007/978-3-0348-8936-0_16

12. Baker, M. Genomes in three dimensions, Nature. 2011;470:289-294, doi:10.1038/470289a

13. International Atomic Energy Agency. Iaea Annual Report 2011 [Internet]. Vienna, Austria; 2011.

14. Pantic I, Harhaji-Trajkovic L, Pantovic A, Milosevic NT, Trajkovic V. Changes in fractal dimension and lacunarity as early markers of UV-induced apoptosis. J TheorBiol [Internet]. 2012;303:87-92, doi:10.1586/14737159.2013.828889

15. Gruel G, Villagrasa C, Voisin P, Clairand I, Benderitter M, Bottollier-Depois J-F, et al. Cell to Cell Variability of Radiation-Induced Foci: Relation between Observed Damage and Energy Deposition. Amendola R, editor. PLoS One [Internet]. 2016 Jan;4(11):e0145786, doi:10.1371/journal.pone. 0145786

16. Neumaier T, Swenson J, Pham C, Polyzos A, Lo AT, Yang P, et al. Evidence for formation of DNA repair centers and dose-response nonlinearity in human cells. Proc Natl AcadSci [Internet]. 2012 Jan 10;109(2):443-8, doi:10.1073/pnas.1117849108

17. Kliauga P, Dvorak R. Microdosimetric Measurements of Ionization by Monoenergetic Photons. Radiat Res [Internet]. 1978 Jan;73(1):1, doi:10.2307/3574570

18. Lorat Y, Brunner CU, Schanz S, Jakob B, Taucher-Scholz G, R?be CE. Nanoscale analysis of clustered DNA damage after high-LET irradiation by quantitative electron microscopy? The heavy burden to repair. DNA Repair (Amst) [Internet]. 2015 Apr;28:93-106, doi:10.1016/j.dnarep.2015.01.007

19. Cavalcanti MB, Fernandes TS, Silva EB, Amaral A. Correlation between radiation dose and p53 protein expression levels in human lymphocytes. 2015;87:1783-1790, doi:10.1590/00013765201520150084 